\title{
A Study Regarding the Effects of Intercropping Celery with Cauliflower and Cherry Tomatoes
}

\author{
Florina-Maria GALEA* (DELEANU), Neculai MUNTEANU, Gabriel-Ciprian TELIBAN, Silvia-Brîndușa \\ HAMBURDĂ
}

Faculty of Horticulture,The University of Agricultural Sciences and Veterinary Medicine, Aleea Mihail Sadoveanu, nr.3, 700490, Iaşi, Romania.

*)Corresponding author, e-mail: florinagalea@gmail.com

BulletinUASVM Horticulture 74(1) / 2017

Print ISSN 1843-5254, Electronic ISSN 1843-5394

DOI:10.15835/buasvmen-hort:12290

\begin{abstract}
It has been proved that intercropping is a suitable approach for vegetable growing providing a high degree of sustainability. Due to its advantages this system reduces the presence of weeds, diseases and pests.

Research was carried out in the experimental field of V. Adamachi farm from USAMV Iași. The biological material consist in three vegetable species: celery, cherry tomatoes and cauliflower and a flower, French marigold, cultivated in two intercropping systems, celery + cherry tomato + French marigold and celery + cauliflower. Biometric evaluations of celery plants were done on the edible part, length and width of the stalk and leaf, and number of leafs per plant.

The obtained results showed in the two intercropping systems that celery plants were well developed, with a rich rosette and intense green colour of leaves. Celery, intercropped with cauliflower has a length and number of stalks slightly higher than the other system.

The aim of this study is to analyze the agronomic and ornamental performances of the intercrop systems of celery with cauliflower and celery with tomatoes.
\end{abstract}

Keywords: celery, intercropping, ornamental

\section{INTRODUCTION}

Celery is an important crop in Romanian vegetable gardens and in its cuisine; this species originates from Asia and the Mediterranean bay. With a large range of uses, from medicine to bio agriculture, celery has many varieties, from which Pascal Giant is one of the most suitable in intercropping systems (Falticeanu and Munteanu, 2003).

Due to its advantages, intercropping systems can be easily used in vegetable growing, even in small family gardens, increasing the sustainability of the environment (Mousavi and Eskandari, 2011).

Intercropping systems were used ever since humans were capable to grow their own vegetables. As time passed, productivity and high yield became more important than a sustainable ecosystem and a balanced consume of resources. In nowadays the desire for a better future for the next generations has brought into attention the advantages that intercropping systems have worldwide.

Studies have shown the advantages of intercropping systems are multiple, a main reason why they are an integrated part of the sustainable agricultural system and the ecological system as well and a base for the biodynamic agriculture (Stoleru, 2008). Advantages such as:

- stability and uniformity of the crop;

- less pesticides and herbicides;

- soil resources used in a judicial way; 

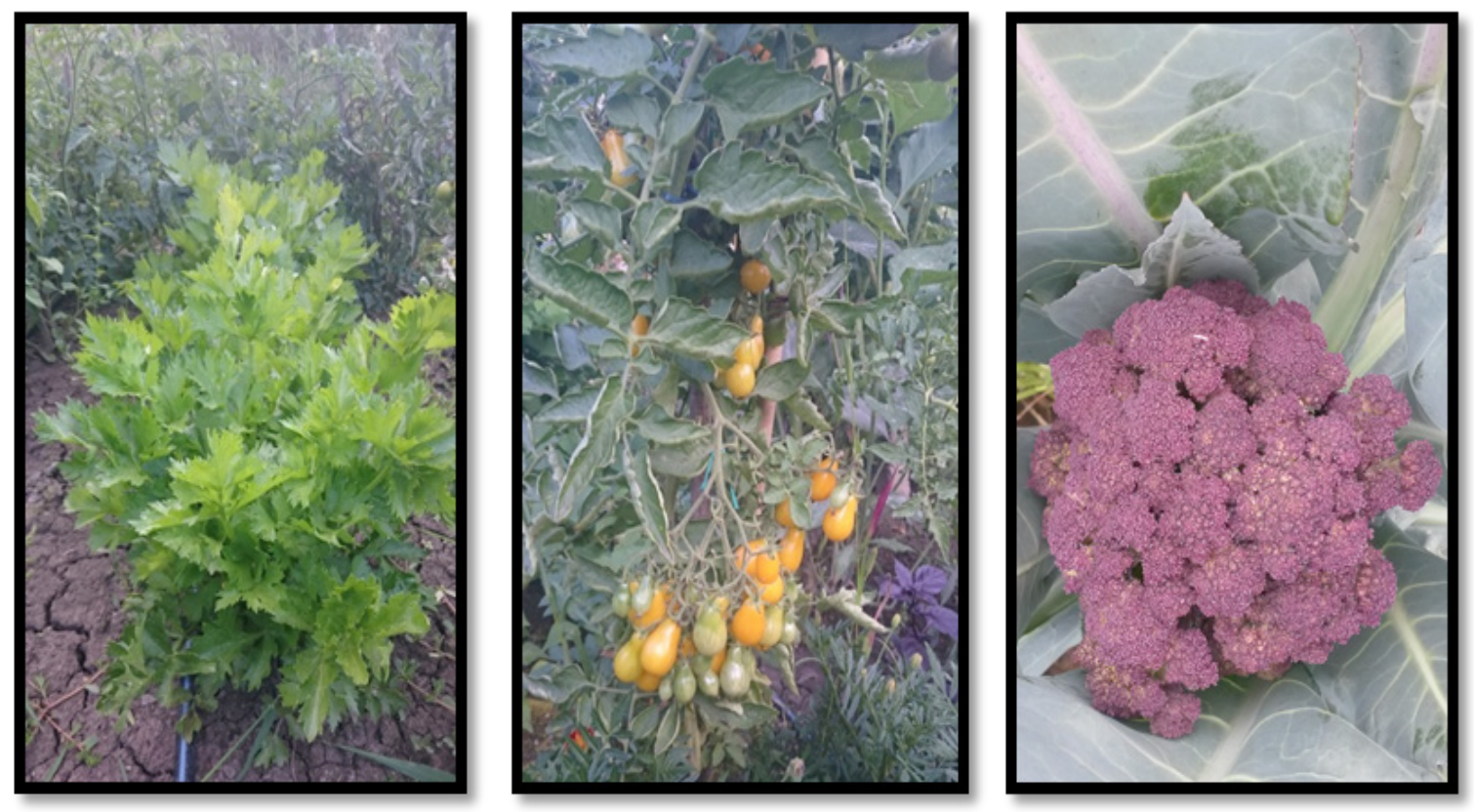

Fig. 1. Biological material used in intercropping experience

(a) Pascal Giant celery (b) Beam s Yellow Pear tomato (c) Di Sicilia Violetto cauliflower

- $\quad$ raising fertility of the soil and biodiversity in the area (Eskandari and Mousavi, 2011);

- As any system it also has disadvantages, if the plant requirements are not respected. In designing an ornamental intercropping system, the main plant requirements are:

- the plant habitus;

- the type of the root system;

- the growth rhythm during the intercropping period;

- the intercropped species must have similar requirements to climatic factors during intercropping;

- the intercropped species must not have common pest or diseases (Ciofu et al, 2003);

An increasing interest in intercropping systems restarted with the Green revolution, when more people became aware of the importance of a sustainable environment development and all that contributes to it. The need for healthy vegetables and fruits and the increasing demand helped flourish this type of agrarian system.

Recent studies showed that intercropping celery with different vegetables plants and nonvegetables, besides decreasing pest attacks, increases the nutrient uptake of the vegetables in this system by forcing them to maximize their biological fixing capabilities (Coolman and Hoyt, 1993). Consumed worldwide celery is found in many family vegetable gardens due to its taste and flavor, for the important role that this specie has in the relationship between compoments of intercropping systems (Bavec et al, 2010). The aim of this study is to analyze the agronomic and ornamental performances of the intercrop system with celery and cauliflower and cerry tomatoes.

\section{MATERIALS AND METHODS}

Theresearch wascarried outin an experimental field of the Vegetable growing Departament, from of Vasile Adamachi farm, belonging to the University of Agricultural Sciences and Veterinary Medicine from Iași, Romania, during 2015-2016 period.

The biological material used in this experiment was represented by celery Pascal Giant cv., Beams Yellow Pear cherry tomato cv., French marigold Nana cv. (a companion flower) and violet cauliflower Di Sicilia Violetto cv (Fig.1.)

The crop was established using seedlings of 50 days. The two intercropping systems consist of celery + cauliflower and celery + tomato + French marigold.

Planting of the seedlings was done at different times, according with the technical recommendation for each species: 15.04 - celery, 25.04cauliflower and 5.05- tomato. Each intercropping system was organized on a $60 \mathrm{~m}^{2}$ acreage. 


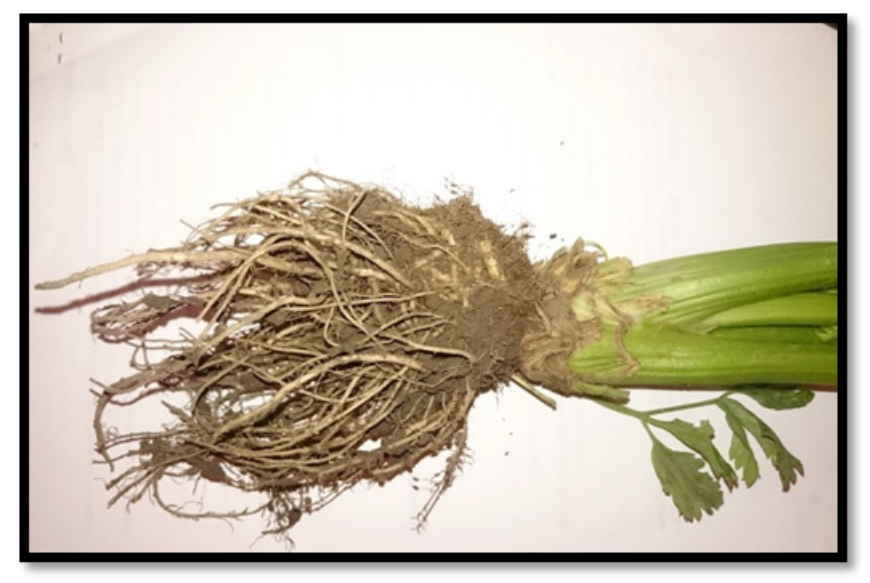

Fig. 4. The root system of celery

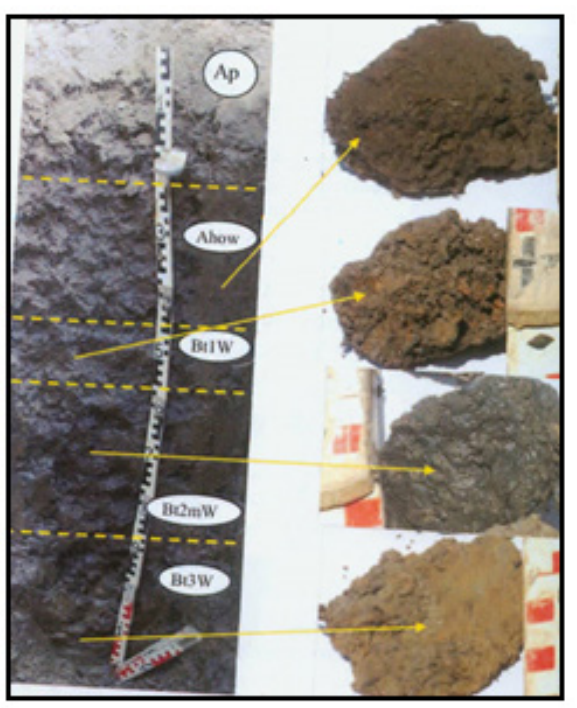

Fig. 2. Profile of the soil in the experimental field (Stoleru et al., 2014)

As an ornamental vegetable design, celery was planted between the rows of cherry tomatoes in the first intercropping system and between the rows of cauliflower in the second intercropping system, at a distance of $30 \mathrm{~cm}$ between plants and an equal distance of $40 \mathrm{~cm}$ from the tomato rows.

During the vegetation period the general carrying practices were done, special attention was paid to watering the crop, mainly in drought days.

Evaluation of agronomical performance of celery crop was according to the experimental data on petiole (stalk) length and width, leaf length and width and number of leaves.

Ornamental value was assessed using special criteria referring to level of morphological de- velopment, spatial display, color harmony, the presences of ornamental organs and features.

Apium graveolens L., ssp. dulce, convar. secalium, Ale. Pascal Giant cv. is an annual species, cultivated for its green leaves, with numerous thin roots, well developed, with a rich leaf rosette (Fig. 4).

The experiment was conducted in accordance with vegetable growing technology and landscaping rules recommended by scientific literature (Stan et al. 2003, Sima 2009 and Iliescu, 2008). The ground for the placement of the experience was plane, well balanced in nutrients with a high content of organic matter (3.4-6.45\%) favorable for vegetable growing, as shown in the profile of the soil presented in Fig. 2 (Stoleru et al., 2014). 


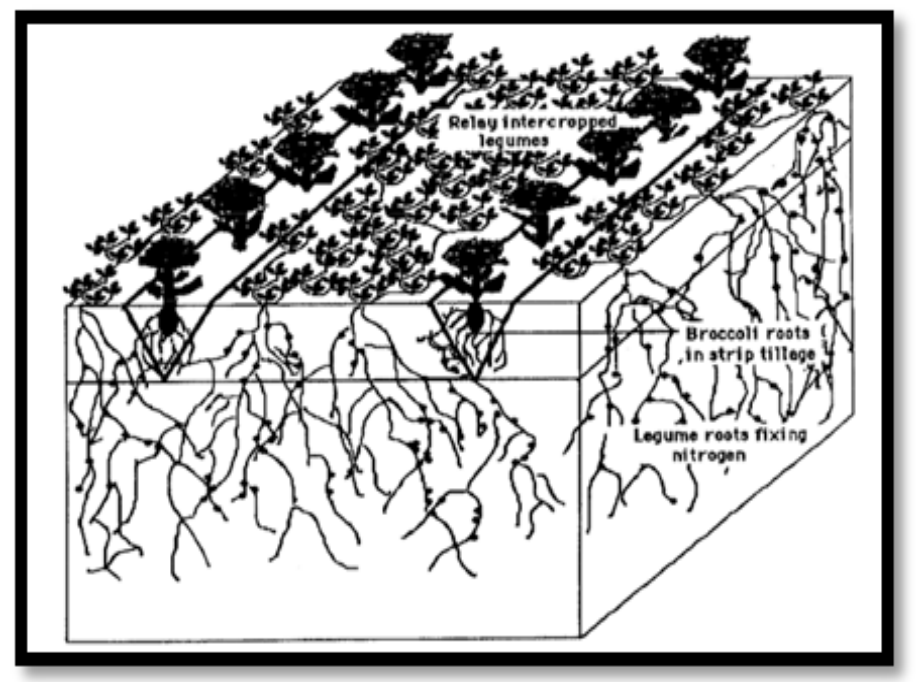

Fig. 3. The representation of root type in an intercropping system (Coolman and Hoyt, 1993)

Tab. 1. Dynamics of stalk length at different harvest time for celery

\begin{tabular}{|c|c|c|c|c|c|c|}
\hline \multirow{2}{*}{ Biometric aspect } & \multirow{2}{*}{$\begin{array}{c}\text { Intercropping } \\
\text { system }\end{array}$} & \multirow{2}{*}{ Year } & \multicolumn{3}{|c|}{ Date of harvest } & \multirow{2}{*}{ Average values } \\
\hline & & & 28.07 & 17.08 & 15.09 & \\
\hline \multirow{4}{*}{ Length of stalk $(\mathrm{cm})$} & $\mathrm{IS}_{1}$ & \multirow{2}{*}{2015} & 8.0 & 11.5 & 15.0 & 11.5 \\
\hline & $\mathrm{IS}_{2}$ & & 13.5 & 9.0 & 17.0 & 13.6 \\
\hline & $\mathrm{IS}_{1}$ & \multirow{2}{*}{2016} & 14.0 & 21.5 & 22.0 & 19.1 \\
\hline & $\mathrm{IS}_{2}$ & & 13.3 & 22.0 & 23.0 & 19.4 \\
\hline
\end{tabular}

Tab. 2. Dynamics of stalk width at different harvest time for celery

\begin{tabular}{|c|c|c|c|c|c|c|}
\hline \multirow{2}{*}{ Biometric aspect } & \multirow{2}{*}{$\begin{array}{l}\text { Intercropping } \\
\text { system }\end{array}$} & \multirow{2}{*}{ Year } & \multicolumn{3}{|c|}{ Date of harvest } & \multirow{2}{*}{ Average values } \\
\hline & & & 28.07 & 17.08 & 15.09 & \\
\hline \multirow{4}{*}{ Width of stalk $(\mathrm{cm})$} & $\mathrm{IS}_{1}$ & \multirow{2}{*}{2015} & 0.5 & 0.6 & 1.2 & 0.7 \\
\hline & $\mathrm{IS}_{2}$ & & 1.0 & 1.2 & 1.0 & 1.0 \\
\hline & $\mathrm{IS}_{1}$ & \multirow{2}{*}{2016} & 0.8 & 1.4 & 1.8 & 1.3 \\
\hline & $\mathrm{IS}_{2}$ & & 1.0 & 1.8 & 2.0 & 1.6 \\
\hline
\end{tabular}

\section{RESULTS AND DISCUSSIONS}

Intercropping celery with cherry tomatoes has showed that the different high of the two species had a large contribution in their development. The height of the tomatoes kept shadow for the celery in the early stages of development, so the evolution was a positive one, wile when the rosette of celery was well developed it kept the soil ripe for a longer time for the tomatoes during the hot summer. In the second intercropping system, celery with cauliflower, the habitus of the plant had a more significant importance in the late state of development.
Another factor that contributed to the well development of the species was the different type of root system (Fig. 3.), as pointed out by Butnariu (1992) and Coolman (1993), the species explored a different depth of soil for nutrient, avoiding the competition that can appear under ground between plants with the same type of system.

These positive intraspecific reactions are of great importance when it comes to a successful crop. As shown by Wang (2013), these reactions are beneficial for both species in the system and 


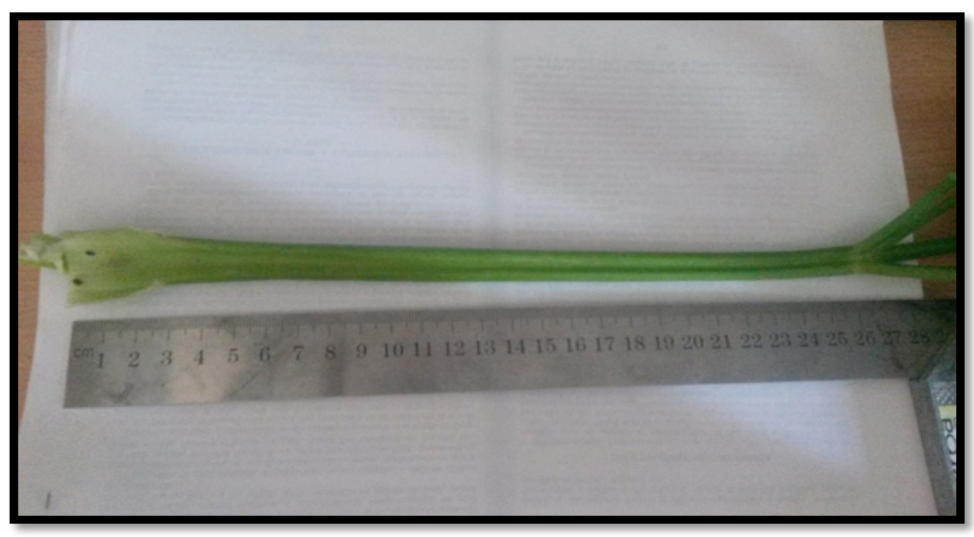

Fig. 4. Pascal Giant stalk

Tab. 3. Dynamics of leaf length at different harvest time for celery

\begin{tabular}{|c|c|c|c|c|c|c|}
\hline \multirow{2}{*}{ Biometric aspect } & \multirow{2}{*}{$\begin{array}{c}\text { Intercropping } \\
\text { system }\end{array}$} & \multirow{2}{*}{ Year } & \multicolumn{3}{|c|}{ Date of harvest } & \multirow{2}{*}{ Average values } \\
\hline & & & 28.07 & 17.08 & 15.09 & \\
\hline \multirow{4}{*}{ Length of leaf $(\mathrm{cm})$} & $\mathrm{IS}_{1}$ & \multirow{2}{*}{2015} & 10.0 & 12.5 & 15.0 & 12.5 \\
\hline & $\mathrm{IS}_{2}$ & & 16.0 & 14.5 & 15.0 & 15.1 \\
\hline & $\mathrm{IS}_{1}$ & \multirow{2}{*}{2016} & 22.0 & 24.0 & 27.3 & 24.4 \\
\hline & $\mathrm{IS}_{2}$ & & 21.3 & 25.3 & 28.5 & 25.0 \\
\hline
\end{tabular}

Tab. 4. Dynamics of leaf width at different harvest time for celery

\begin{tabular}{|c|c|c|c|c|c|c|}
\hline \multirow{2}{*}{ Biometric aspect } & \multirow{2}{*}{$\begin{array}{c}\text { Intercropping } \\
\text { system }\end{array}$} & \multirow{2}{*}{ Year } & \multicolumn{3}{|c|}{ Date of harvest } & \multirow{2}{*}{ Average values } \\
\hline & & & 28.07 & 17.08 & 15.09 & \\
\hline \multirow{4}{*}{ Width of leaf $(\mathrm{cm})$} & $\mathrm{IS}_{1}$ & \multirow{2}{*}{2015} & 10.0 & 12.5 & 15.0 & 12.5 \\
\hline & $\mathrm{IS}_{2}$ & & 12.0 & 13.0 & 17.3 & 14.1 \\
\hline & $\mathrm{IS}_{1}$ & \multirow{2}{*}{2016} & 13.0 & 13.5 & 23.5 & 16.6 \\
\hline & $\mathrm{IS}_{2}$ & & 12.0 & 13.0 & 22.0 & 15.6 \\
\hline
\end{tabular}

they play an important role in yield production and well development of the species intercropped.

In his studies Paven (1998) describes the positive reactions as mechanism in which the associated species help one another, by releasing certain substances in the soil, which inhibits weeds, but not the associated species. This mechanism is known worldwide as allopathy, an important element in maintaining the balance between weeds, diseases and pests in the crop (Valceva et al., 2013).

Underlined by many others (Eskandari and Mousavi, 2011; Bavec et al, 2010; Falticeanu and Munteanu, 2003;), the benefits that celery has on the crops it is associated with are important in a family vegetable garden, because it contributes to the stability of the environment, as green nods, enhancing sustainability of the city. The current study aims to confirm these results and apply them in future developments.

Biometric aspects of celery stalk presented in Tab. 1 and Tab. 2 (length and width of stalk) show that the plants had higher values in 2016 compared to 2015 in both intercropping systems, reveling the importance that water has in the first stages of development. The significant difference was caused by lower air humidity, and only 156.8 mm of rain water from April to August, much lower than the normal for this period $294.7 \mathrm{~mm}$ (Agro expert weather data from Adamachi field).

The average values of stalk length in 2016 for the two intercropping systems are close 19.1 $\mathrm{cm}\left(\mathrm{IS}_{1}\right)$ and $19.4 \mathrm{~cm}\left(\mathrm{IS}_{2}\right)$, which reveals the 


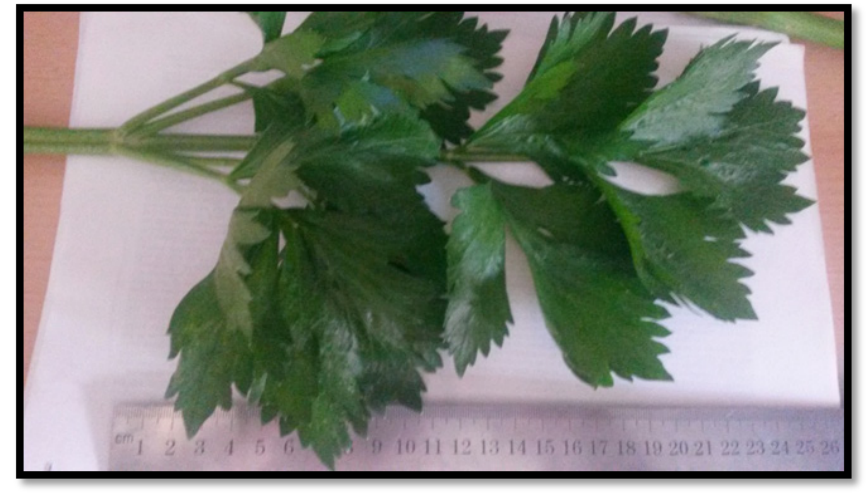

Fig. 5. Celery leaf - leanght detail

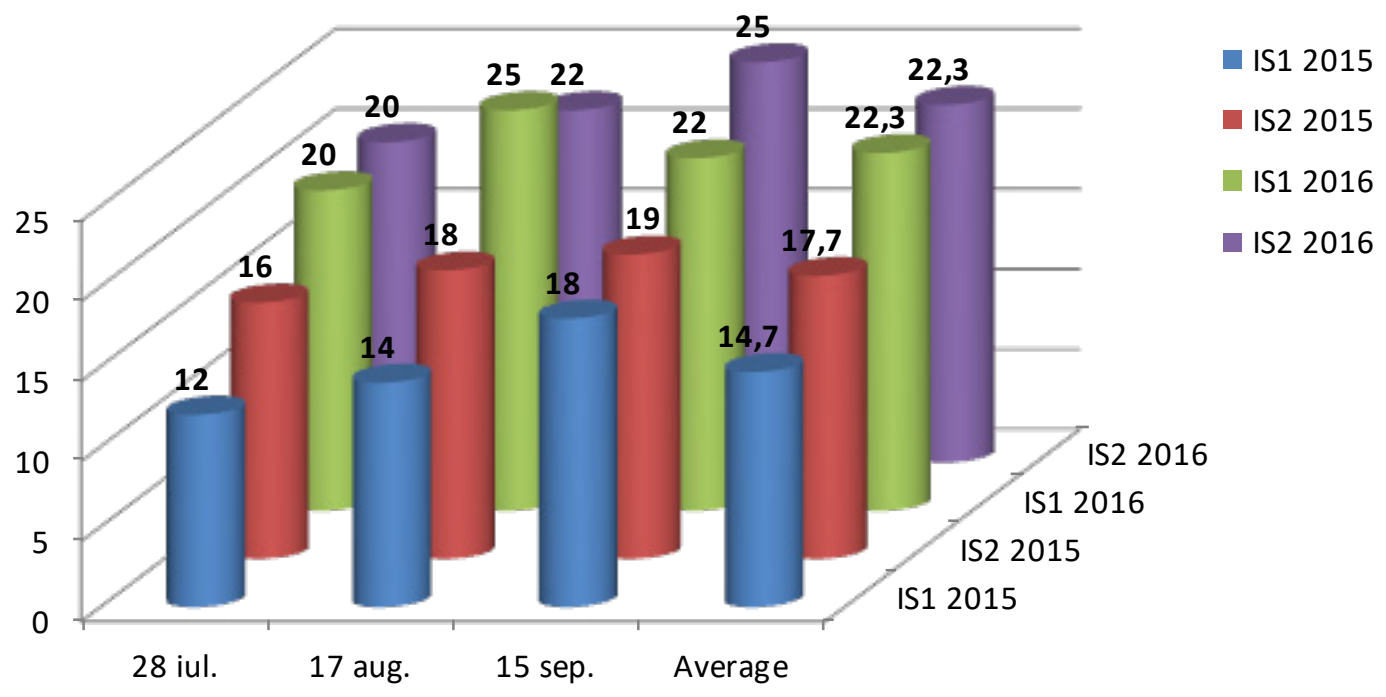

Fig. 4. Dynamic harvest of celery leafs

important effect that climatic factors have on the development of celery.

The length of the stalk in 2016 had an average of $22.0-23.0 \mathrm{~cm}$ with a maximum of $26.0 \mathrm{~cm}$ in IS $_{2}$ (Fig. 4).

Compared to the average values for leaf in 2015 between the two intercropping systems, in 2016 the biometric values resulted from Tab. 3 and Tab. 4 are higher and close, $24.4 \mathrm{~cm}\left(\mathrm{IS}_{1}\right)$ and $25 \mathrm{~cm}\left(\mathrm{IS}_{2}\right)$ for length of leaf in 2016 and $16.6 \mathrm{~cm}$ (

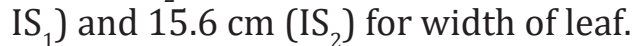

In the early stages of development, the second intercropping system, celery with purple cauliflower, presented higher values in all biometric aspects of the edible part of celery.

The fact that we used seedling in the two intercropping systems, showed that tomatoes and celery competed in the early stages of development for nutrients, because of their low developed root.
The values in Tab. 1, Tab. 3 and Tab. 4 present that by the end of summer the length of the celery stalk for the first system was bigger than the one in the second system, but the leafs were better developed, a factor that had a major role in the control of the pest attack of the cabbage white butterfly (Pieris rapae), which was spotted in the area on the pheromone traps in the vegetable garden

Compared to the first and second harvest, the average morphological values showed that a lower temperature in September and a higher humidity in soil contributed in an active manner to higher values of the morphological characters of edible part of celery in both intercropping systems.

The values presented in Fig. 4 prove that the number of leaves is higher for the celery when intercropped with cauliflower in both years of study. 


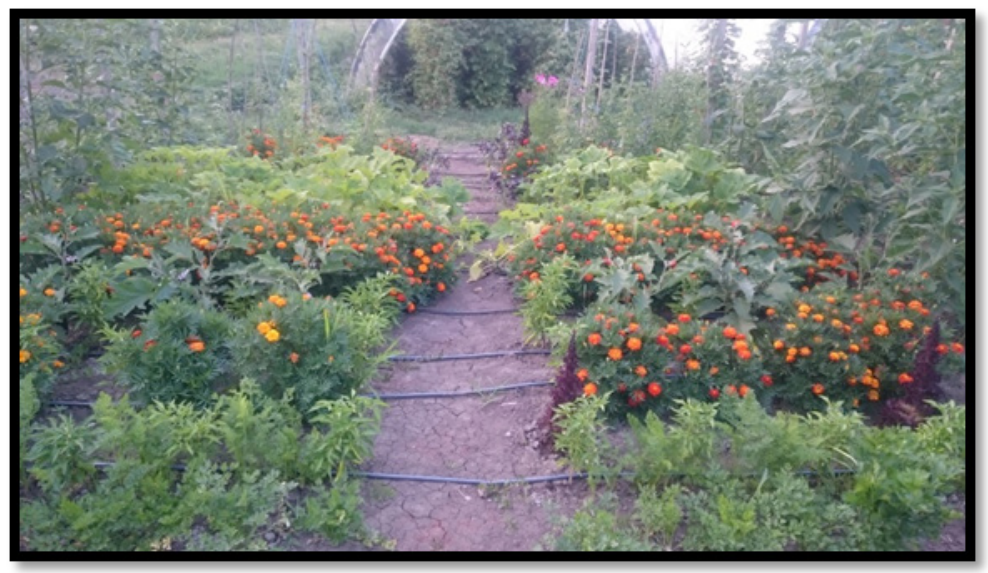

Fig. 5. Detail of an ornamental vegatable garden

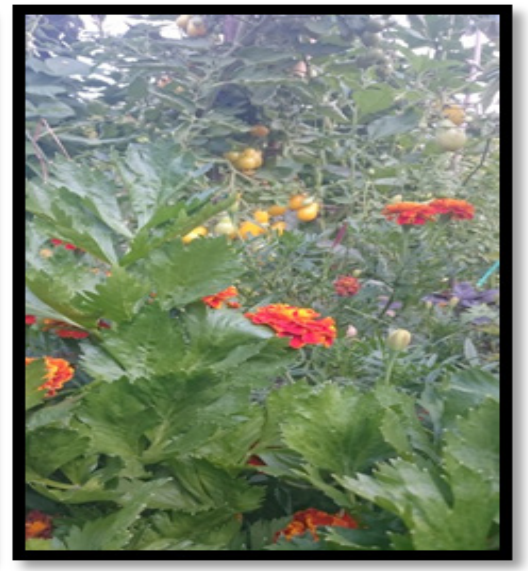

Fig. 6. Celery and tomatoes
The dynamics of harvesting of leaves revealed an increase of biometric values with each harvest, in both years of study. The year 2016 presented higher values in both systems compared with 2015.

As a part of an ornamental intercropping system (Fig. 5.), the species in the two systems have utilitarian and ornamental purpose in the same time. The intense green leafs of celery combined with the bright yellow of the cherry tomatoes and the vibrant orange of French marigold (Tagetes patula), a companion plant in the ornamental intercropping system, is a spectacle for the human eye and a good trio against pest (Tringovska et al., 2015) as it is show in Fig. 6. The second intercropping system, between celery and purple cauliflower, showed the contrast between the green leafs of celery and the dark and intense color of the cauliflower.

\section{CONCLUSIONS}

Comparing the results of the morphological characters obtained in 2015 and 2016; it is shown that cauliflower is a better match for celery in an intercropping system, than cherry tomatoes. The companion species used offered unity to the ornamental intercropping system, enhancing its ornamental value, but in the same time helping against pests and disease. An important element in the good developing of the species was represented by the quantity of rain water, which was much lower in the year 2015, affecting the habitus of celery plant, in comparison to the harvest in 2016. By using intercropping systems biodiversity was increased and usage of chemicals was reduced.

\section{REFERENCES}

1. Bavec M, Zuljan M, Robacer M, Bavec F (2010). White cabbage productivity in intercropping production systems. International Horticultural Congress on Science and Horticulture for People (IHC2010): International Symposium on Organic Horticulture: Productivity and Sustainability, Lisbon, Portugal.

2. Butnariu H, Indrea D, Petrescu C, Savițchi P, Chilom P, Ciofu R, Popescu V, Stan N (1992). Legumicultură. Editura Didactică şi Pedagogică R.A., Bucureşti, 84-86 p.

3. Coolman RM, Hoyt GD (1993). Increasing Sustainability by Intercropping. July-September 1993 3(3).

4. Fălticeanu M, Munteanu N, (2006). Plante utile pentru grădina dumneavoastră. Editura Tipo Moldova, Iaşi, 39$40 \mathrm{p}$.

5. Iliescu AF, 2008. Arhitectură peisageră. Editura Ceres, București, 137-151 p.

6. Mousavi SR, Eskandari H (2011). A General Overview on Intercropping and Its Advantages in Sustainable Agriculture, J. Appl. Environ. Biol. Sci., 1(11) 482-486 p.

7. Paven I 1998. Cercetări privind folosirea intensivă a solariilor prin culture associate şi succesive de legume. USAMV Cluj-Napoca, PhD Diss. Abstract.

8. Sima R (2009). Legumicultura. Sursă de hrană şi potenţial ornamental. Editura Academic Pres, Cluj-Napoca, 21-23 p.

9. Stan NT, Munteanu N, Stan TN (2003). Legumicultură, vol. III. Editura "Ion Ionescu de la Brad", Iaşi, 188-190 p.

10. Stoleru V (2008). Cercetări privind oportunitatea cultivării legumelor în sistemul de agricultură sustenabilă (durabilă), PhD Diss., Iaşi, 16-33 p. 
11. Stoleru V, Munteanu N, Sellito MV (2014). New approach of organic vegetable systems. ARACNE Editrice, Ariccia, 91-98 p.

12. Tringovska I, Yankova V, Markova D, Mihov M (2015). Effect of companion plants on tomato greenhouse production. Journal Scientia Horticulturae 2015 Vol. 186, 31-37 p.
13. Valcheva E, Popov V (2013). Role of the alleopathy in mixed vegetable crops in the organic farming. Scientific Papers. Series A. Agronomy, Vol. LVI.

14. Wang JH, Chen T, Lin WX (2013). Plant allelopathy types and their application in agriculture. Journal Zhongguo Shengtai Nongye Xuebao / Chinese Journal of EcoAgriculture 2013 Vol. 21 No. 10, 1173-1183.

15. ***AgroExpert weather data from Adamachi field. 